\title{
Effect of Silica Nanoparticles on Cultured Central Nervous System Cells
}

\author{
Yuriko Inoue ${ }^{1 *}$, Hiromitsu Ezure1, Junji Ito², Chika Sawa1, Masato Yamamoto ${ }^{3}$, Harumi Hata ${ }^{4}$, \\ Hiroshi Moriyama', Yoshinobu Manome ${ }^{5}$, Naruhito Otsuka ${ }^{1}$ \\ ${ }^{1}$ Department of Anatomy, Showa University School of Medicine, Tokyo, Japan \\ ${ }^{2}$ School of Nursing and Rehabilitation Sciences, Showa University Department of Nursing, Tokyo, Japan \\ ${ }^{3}$ Department of Chemistry, Faculty of Arts and Sciences at Fujiyoshida, Showa University, Tokyo, Japan \\ ${ }^{4}$ Center for Research and Development in Pharmacy Education, School of Pharmacy, Nihon University, Chiba, Japan \\ ${ }^{5}$ Division of Molecular Cell Biology, Core Research Facilities for Basic Science, Research Center for Medical Sciences, The Jikei \\ University School of Medicine, Tokyo, Japan \\ Email: *inoue1978@med.showa-u.ac.jp
}

How to cite this paper: Inoue, Y., Ezure, H., Ito, J., Sawa, C., Yamamoto, M., Hata, H., Moriyama, H., Manome, Y. and Otsuka, N. (2018) Effect of Silica Nanoparticles on Cultured Central Nervous System Cells. World Journal of Neuroscience, 8, 146-156. https://doi.org/10.4236/wjns.2018.82013

Received: January 30, 2018

Accepted: May 4, 2018

Published: May 7, 2018

Copyright (C) 2018 by authors and Scientific Research Publishing Inc. This work is licensed under the Creative Commons Attribution International License (CC BY 4.0).

http://creativecommons.org/licenses/by/4.0/

\begin{abstract}
Nanotechnology is developing rapidly and the production of novel man-made nanoparticles is increasing. However, the effects of these particles on human health are unevaluated. Depending on particle size and the surface properties, nanoparticles may have the potential to affect human health. In recent studies, several silica nanoparticles $(<100 \mathrm{~nm})$ were shown to be penetrating into the brain. Thus, it is important to understand the influence of these nanoparticles on the central nervous system. In this study, we investigated the toxicological influence of nanoparticles on cortical cultured neurons isolated from embryonic day 18 Wister rats. Cortical cultured neurons at 21 days in vitro (DIV) were treated with $30 \mathrm{~nm}$ silica nanoparticles for $1 \mathrm{hr}$. Many neurons were damaged immediately more than at $0.01 \mathrm{mg} / \mathrm{ml}$ concentration of silica. Cell damage was also assessed using the lactate dehydrogenase (LDH) assay and the reactive oxygen species (ROS) assay. We revealed that the Neuro-toxicological mechanisms were due to membrane permeability. It was suggested that cell membrane permeability was enhanced because of ROS generation. Given these results, it will be important to determine the effect of nano-silica particles in vivo and identify the extent of neuronal damage.
\end{abstract}

\section{Keywords}

Silica, Nanoparticles, Toxicity, Primary Cultured Cortex Neuron, LDH, ROS 


\section{Introduction}

Nanotechnology is developing rapidly and the production of novel manufactured nanoparticles is increasing. Depending on the particle size and the surface properties, nanoparticles have the potential to affect human health. Some nanoparticles have received considerable attention, because of their useful properties, such as high conductivity [1], biocompatibility [2] [3], and stability [3]. These nanoparticles can be used in various application fields including bioelectronics and biomedical applications [4]-[9]. However, the effects of these particles on human health are not elucidated.

Silica nanoparticles have also been formulated for medications and foods, however, the potential for ROS generation may lead to the development of immunologic diseases [10]. Generation of ROS has been reported in primary cultures of microglia [1] [3] [11] [12]. Activation of brain microglia that produces various neurotoxic factors including cytokines and ROS has been increasingly associated with dopaminergic degeneration of neurons induced by various toxicants [13].

Recent several in vivo studies suggested that smaller than $100 \mathrm{~nm}$ nanoparticles $(1 \mathrm{mg} / \mathrm{ml})$ have the ability to reach the brain tissue [2]. In our previous studies, concentration of $30 \mathrm{~nm}$ silica nanoparticles $(1 \mathrm{mg} / \mathrm{ml})$ can be transported into the brain through the Blood-brain barrier (BBB) [14] [15]. Moreover, some nanoparticles can penetrate into the brains of murine fetuses through the placenta by intravenous administration to pregnant mice. The effects of nanoparticles and their distribution in various organs have been studied in vivo and have provided important insights on the toxicological mechanisms involved in cell damage. However, few reports have addressed the effect of nanoparticles on the central nervous system. For example, although a study has shown that silica particles were present in the adult-mouse brain following transdermal absorption [16] and in mouse - fetuses in utero [2], it remains unclear what is the effect of nanoparticles on neurons after penetration into the brain. Therefore, in order to monitor the toxic effects of silica nanoparticles following direct contact with neurons, we used primary cultures of cortical neurons isolated from rat embryos.

In our previous study, we showed size-dependent penetration of silica nanoparticles with a BBB model in vitro. Moreover, $300 \mathrm{~nm}$ large silica particles did not cross and not deliver the placental-maternal barrier [14] [15]. We also showed that the apparent permeability coefficient in the model for the $30 \mathrm{~nm}$ silica particles was higher than those of the larger silica particles (100 and $400 \mathrm{~nm}$ ) and was higher than those of the smaller silica particles $(22 \mathrm{~nm})$ [14] [15]. Therefore, we used $30 \mathrm{~nm}$ silica nanoparticles in this study.

We used silica in this paper because in recent years, the use of silica nanoparticles has been extended to biomedical and biotechnological fields. There is a lack of information regarding the health and environmental implications of manufactured nanomaterial to human. It is important to carry out observation 
from a viewpoint of silica. However, the silica needs to evaluate the toxicity by contact into a cell without toxicity (an exception is a lung) outside a body [17].

A previous report showed that when intraperitoneal injection of quantum dots to mice was carried out, quantum dots were detected in several regions of the mouse brain, thalamus (8.76\%), brain stem (29.4\%) and cortex (21.36\%) [4]. Interestingly, this report suggested the particles distributed not only to the circumference of a blood vessel but to cerebral parenchymatous tissue in the cerebral cortex. For this reason, we used cerebral cortex primary cultured neurons for the evaluation of nanoparticle's exposure [4]. Based on previous reports that $100 \mathrm{~nm}$, or smaller, particles can penetrate into the brain [16], we observed cell damage using silica nanoparticles and elucidated the mechanism of neuronal toxicity using the ROS assay and LDH assay.

\section{Material and Methods}

\subsection{Cell Culture}

Primary cultures of cortical neurons were prepared as described previously [18]. Briefly, the cortex was isolated from embryonic day 18 Wistar rats, treated with papain $\left(100 \mathrm{mg} / \mathrm{ml}\right.$, Worthington, Lakewood, NJ, USA) for $10 \mathrm{~min}$ at $37^{\circ} \mathrm{C}$. Dissociated neurons were seeded onto $1 \mathrm{mg} / \mathrm{ml}$ poly-L-lysine (PLL, Shigma) coated 96-well microplates $\left(1 \times 10^{4}\right.$ cells/well $)$ for LDH assay, or PLL coated coverslips (Matsunami) in $6 \mathrm{~cm}$ dish $\left(15-\mathrm{mm}\right.$ diameter, $\left.2-3 \times 10^{4} \mathrm{cells} / \mathrm{cm}^{2}\right)$ for microscopy. These neurons were cultured in Neurobasal-A medium (Invitrogen) supplemented with $2 \%(\mathrm{v} / \mathrm{v})$ B-27 (Invitrogen), $0.5 \mathrm{mM}$ glutamine and maintained in a humidified atmosphere of $5 \% \mathrm{CO}_{2}$ at $37^{\circ} \mathrm{C}$ for $21-28$ days. One-half of the medium was changed each week. All experiments were performed in accordance with the Animal Research Committee at Showa University.

\subsection{Exposure to Silica Nanoparticle}

Primary cultured cortical neurons were exposed to fluorescent rhodamine $30 \mathrm{~nm}$ silica and non-labeled $30 \mathrm{~nm}$ silica particles (Micromod Partikeltechnologie $\mathrm{GmbH}$, Germany) for $10 \mathrm{~min}, 30 \mathrm{~min}$ and $1 \mathrm{hr}$ at concentrations of $0.01,0.1$ and $1 \mathrm{mg} / \mathrm{ml}$. These particles contain high amount of covalently bound fluorescence dye in the silica matrix and are extremely stable in organic solvents and buffers and no toxic effects come from the covalently bound fluorescence dyes. We checked the characterization of the nanoparticles by dynamic light scattering. The diameter of the silica nanoparticles in culture medium, which was measured with dynamic light scattering, was $32.29 \pm 0.32 \mathrm{~nm}$. Degree of dispersion is Polydispersity index $(\mathrm{PdI})=0.037 \pm 0.011$.

\subsection{Immunocytochemistry}

After exposure to silica nanoparticle, cells were fixed for Immunocytochemical analysis. Primary cultured neurons were fixed with $4 \%(\mathrm{w} / \mathrm{v})$ paraformaldehyde in phosphate-buffered saline (PBS) for $30 \mathrm{~min}$. Cells were permeabilized with 
$0.2 \%(\mathrm{v} / \mathrm{v})$ Triton X-100 in PBS for $5 \mathrm{~min}$ and incubated with $8 \%(\mathrm{w} / \mathrm{v})$ bovine serum albumin in PBS for $30 \mathrm{~min}$. MAP2 is a microtubule protein. These cells were stained with mouse anti-MAP2 antibody (1:400, Chemicon) and Alexa Fluor 488 and 543 conjugated second anti-mouse IgG antibody (1:200, Invitrogen) which appeared to remain healthy by observing the imaging of neuronal morphology [19] [20]. The cells were examined under an LSM510 laser scanning confocal microscope (Zeiss).

\subsection{Cellular Damage Assays}

For the measurement of $\mathrm{LDH}$ release from neurons, cell damage was monitored using the Roche Applied Science Cytotoxicity Detection Kit (Roche Applied science) according to the manufacturer's protocol and following exposure to different concentrations $(0.01,0.1$ and $1.0 \mathrm{mg} / \mathrm{ml})$ of silica nanoparticle. The 490 $\mathrm{nm}$ absorption of formazans as an indicator of $\mathrm{LDH}$ releases were measured with TriStar 2 LB942 plate reader (Berthold Technogies). TritonX-100 (2\% $(\mathrm{v} / \mathrm{v}))$ was used as a positive control. The ROS assay was performed using CelIROX Green Reagent (Invitrogen) for high-throughput screening. This is a fluorogenic probe for measuring oxidative stress in live cells. The cell-permeant dye is weakly fluorescent while in a reduced state and exhibits bright green photostable fluorescence upon oxidation by ROS and subsequent binding to DNA, with absorption/emission maxima of 485/520 nm. The CellROX Green images were examined under an LSM510 laser scanning confocal microscope (Zeiss).

\section{Results}

We investigated effects of rhodamine-labeled $30 \mathrm{~nm}$ silica nanoparticle on primary cultures of rat cortical neurons. Because primary cultured neurons were still small at DIV 7, we used primary cultured cortex neurons at DIV 7. Neurons at DIV 7 without nanoparticle became large and nerve networks with neurons each other (Figure 1).

In order to investigate the reaction after silica nanoparticle penetration in acute phase, we exposure the silica nanoparticle to neurons for $1 \mathrm{hr}$. Figure 2(a) shows control 21 DIV cultured neurons without nanoparticle that formed dendritic networks. Figure 2 shows the concentration dependence of the silica nanoparticle exposure. MAP2 is a neuron-specific cytoskeletal protein that stabilizes dendritic shapes during neuron's development. We observed with large magnification at Figure 2 so that the situation of neurons and silica nanoparticles could observe finely. The dendrite of the neural cells decreased by the increase in silica concentration (Figures 2(b)-(d)). Furthermore, when the silica concentration increased, the form of the soma began to collapse and the dendrite of the cell body was disappeared (Figures 2(b)-(d)). No cells were remained at the $1 \mathrm{mg} / \mathrm{ml}$ concentration.

In order to observe the localization of the silica nanoparticle, we magnified the merged images. As shown in Figure 2, we observed the localization of the silica 
(a)

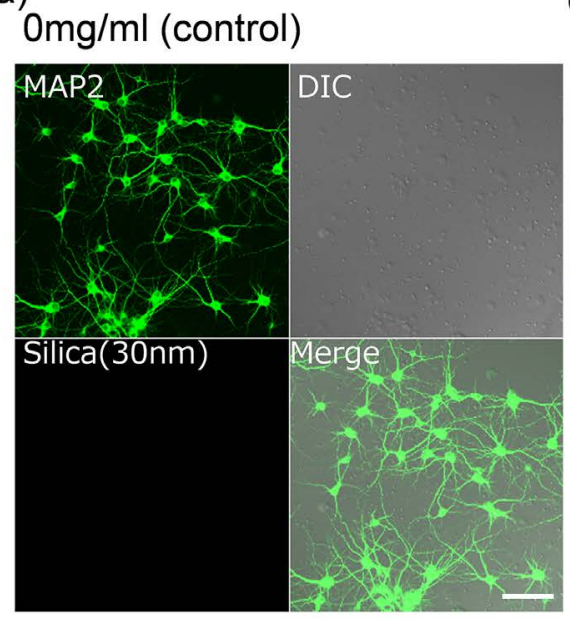

(c)

\section{$0.1 \mathrm{mg} / \mathrm{ml}$}

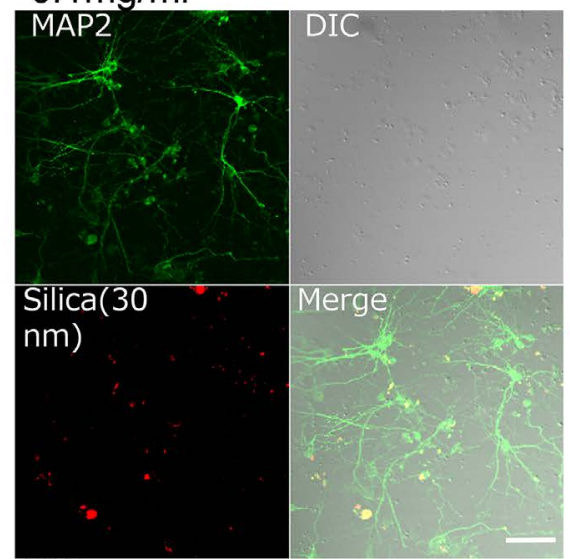

(b) $0.01 \mathrm{mg} / \mathrm{ml}$

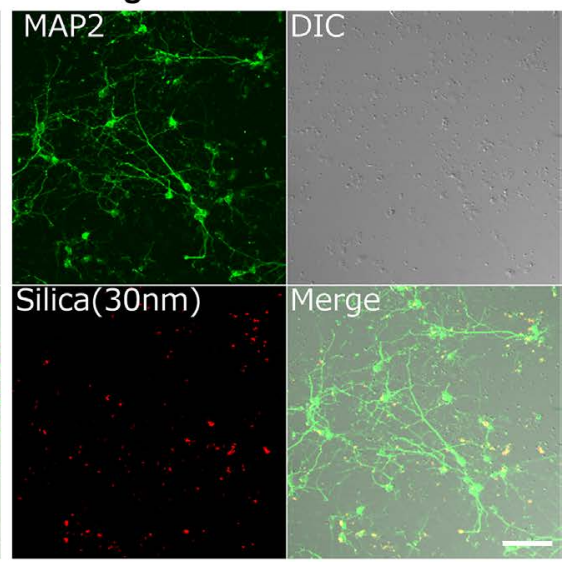

(d)
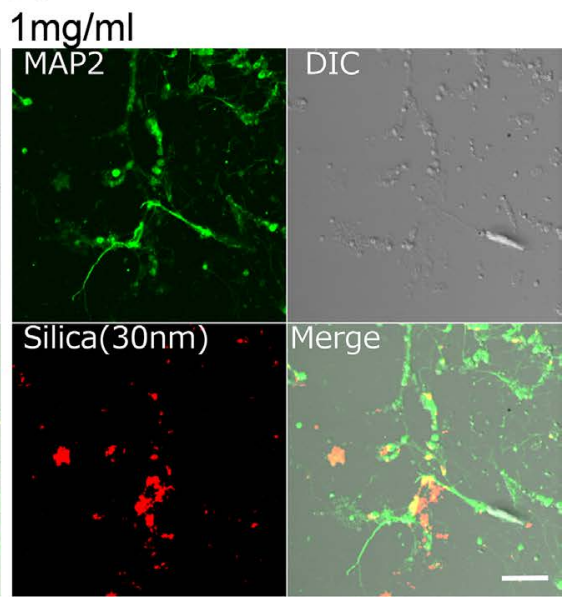

Figure 1. Effect of rhodamine labeled $30 \mathrm{~nm}$ silica nanoparticle on primary cultured cortical neurons (low magnification) at DIV 7. (a) Control (no nanoparticles) and (b), (c) and (d) cells treated with rhodamine labeled $30 \mathrm{~nm}$ silica nanoparticle $(0.01,0.1$ and 1 $\mathrm{mg} / \mathrm{ml}$, respectively) for $1 \mathrm{hr}$. Endogenous MAP2 (green), silica nanoparticle (red) and DIC (Differential interference contrast). We examined 40 neurons with each condition. Scale bars $=200 \mu \mathrm{m}$.

nanoparticle at neurons. There was very little co-localization between MAP2 and silica nanoparticle (Figure 2), suggesting that there was no active uptake of silica nanoparticle into the cell. However, when silica nanoparticle was in contact with neurons at high concentrations $(0.1 \mathrm{mg} / \mathrm{ml}$ or $1 \mathrm{mg} / \mathrm{ml})$, the strength MAP2 staining decreased at neurons. In order to measure neuronal cell death quantitatively, the cell damage was measured by means of LDH assay (Figure 3 ). The $\mathrm{LDH}$ assay detects the leakage of intracellular components due to cell membrane damage and the leakage suggests either necrosis or early stage apoptosis. Colorimetric assay for the quantification of cell death and cell lysis, based on the measurement of $\mathrm{LDH}$ activity released from the cytosol of damaged cells into the supernatant. We demonstrated $\mathrm{LDH}$ assay at $0.01,0.1$ and $1 \mathrm{mg} / \mathrm{ml}$ concentration of silica nanoparticle at 10 and $30 \mathrm{~min}$, respectively. Within $10 \mathrm{~min}$, there 
(a)

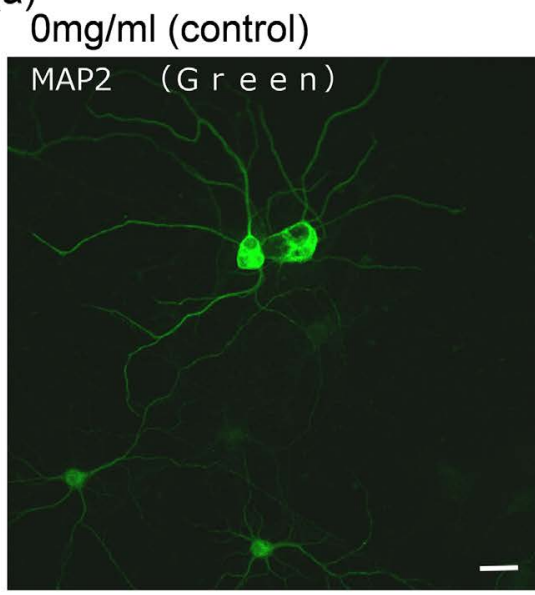

(c)

\section{$0.1 \mathrm{mg} / \mathrm{ml}$}

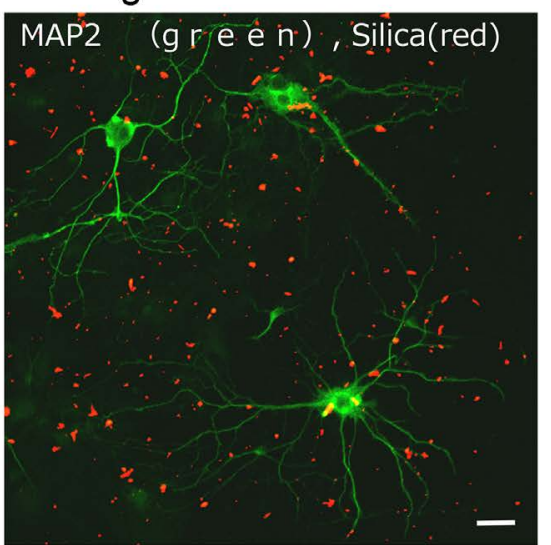

(b)
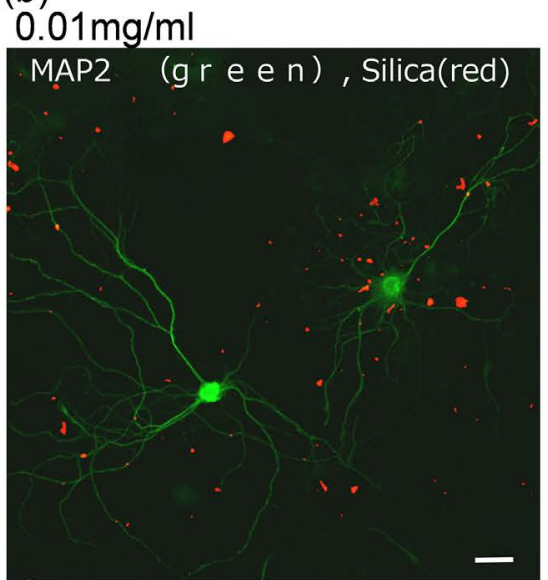

(d)

$1 \mathrm{mg} / \mathrm{ml}$

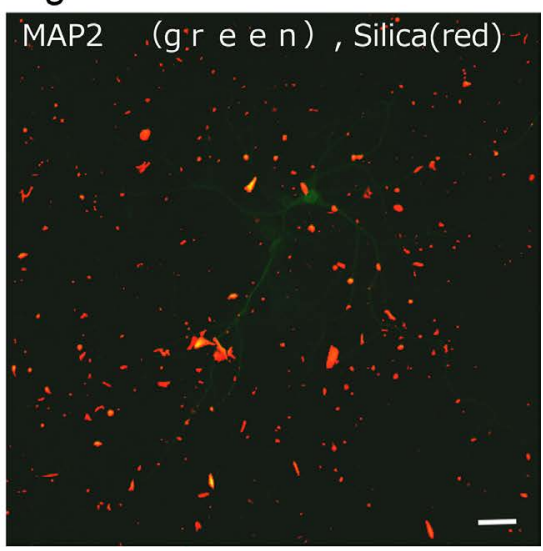

Figure 2. Effect of rhodamine labeled $30 \mathrm{~nm}$ silica nanoparticle on primary cultured cortical neurons at DIV21. (a) Control (no nanoparticles) and (b), (c) and (d) cells treated with rhodamine labeled $30 \mathrm{~nm}$ silica nanoparticle $(0.01,0.1$ and $1 \mathrm{mg} / \mathrm{ml}$, respectively) for $1 \mathrm{hr}$. Endogenous MAP2 (green), silica nanoparticle (red) and DIC. We examined 40 neurons with each condition. Scale bars $=50 \mu \mathrm{m}$.

are no significant differences between all the concentrations; however, higher cell damage rates were observed the all concentrations during $30 \mathrm{~min}$ exposure (Figure 3).

In order to investigate the mechanism of the leakage from neurons, we examined the effect of ROS generation using a green fluorescent indicator, following co-culture with $30 \mathrm{~nm}$ fluorescent silica particles for $30 \mathrm{~min}$. We observed the green fluorescence in the cell bodies of neurons where the axial fiber disappeared, which suggests that ROS production lead to neuronal cell death (Figure $4(\mathrm{~b}))$.

\section{Discussion}

In this study, we measured the effects of the silica nanoparticle on primary cultures of cortical neurons using rhodamine-labeled $30 \mathrm{~nm}$ silica nanoparticle. 


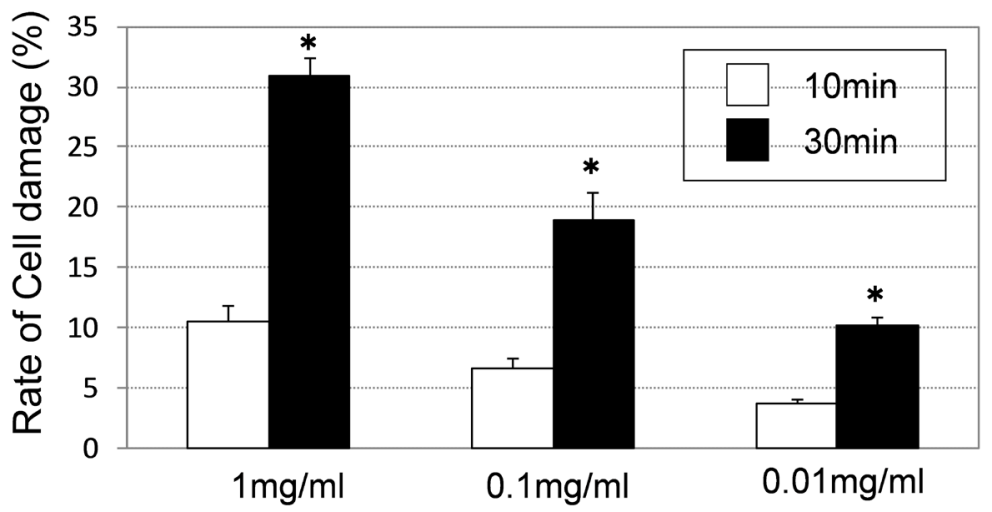

Figure 3. Rate of cell damage using LDH assay during 10 and 30 min exposure to rhodamine labeled $30 \mathrm{~nm}$ silica nanoparticle $(0.01,0.1$ and $1 \mathrm{mg} / \mathrm{ml})$. The rates of OD $490 \mathrm{~nm}$ (\% of positive control) at 10 and 30 min were compared with 0 min (0\%). TritonX-100 (2\% $(\mathrm{v} / \mathrm{v}))$ was used as a positive control. White bar $=10 \mathrm{~min}$ and Black bar $=30 \mathrm{~min}$. The differences between control $(0 \mathrm{mg} / \mathrm{mL}, 0 \mathrm{~min})$ and silica particles' treatments $(10 \mathrm{~min}$ and $30 \mathrm{~min})$ were analyzed with Two-way ANOVA test. $\mathrm{P}<0.05\left(^{*}\right)$. Error bars represent \pm SD. $\mathrm{N}=10$ wells.

$0 \min$

$30 \mathrm{~min}$
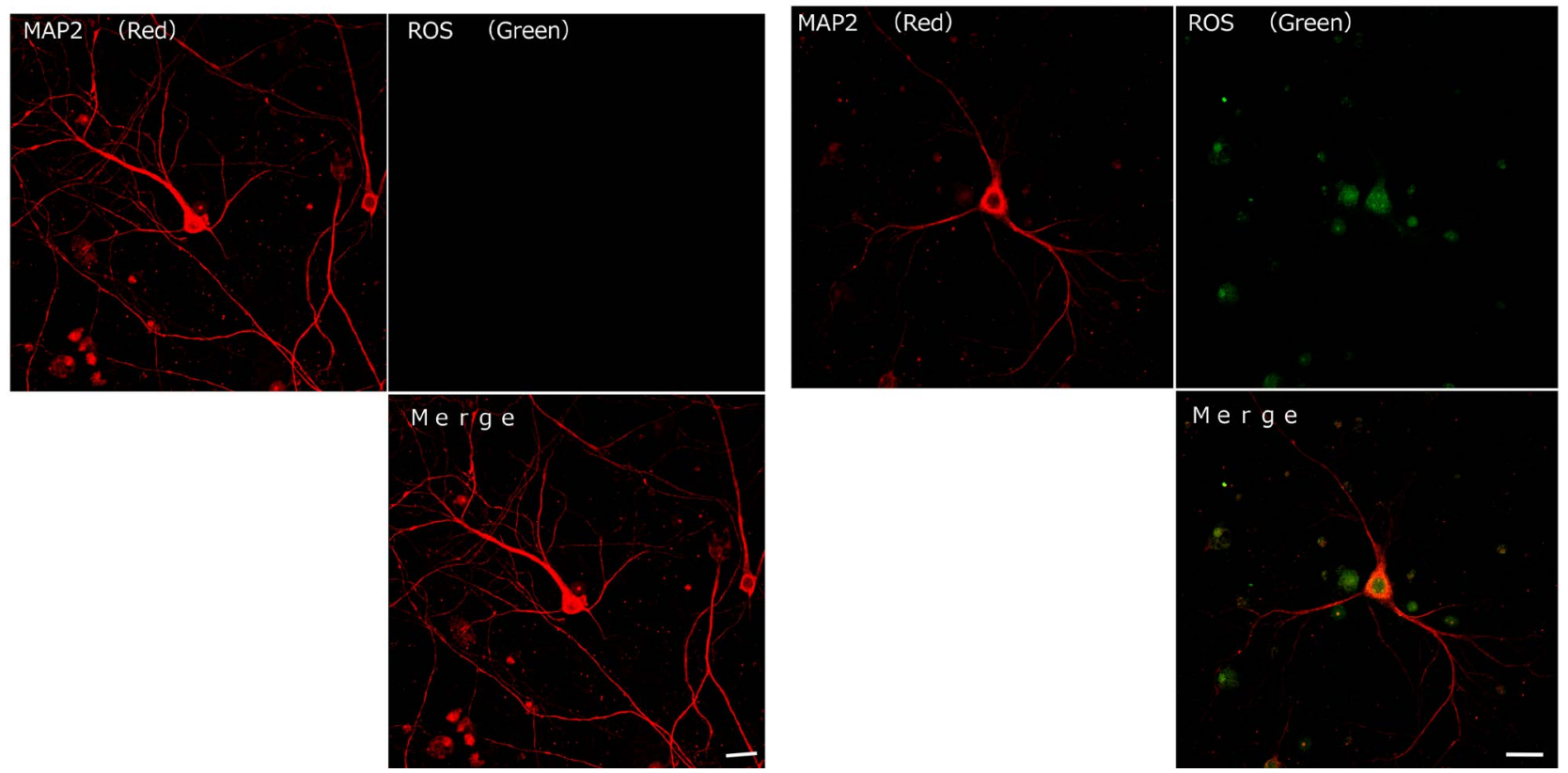

(a)

(b)

Figure 4. Effect of exposure to non-labeled $30 \mathrm{~nm}$ silica particles $(1 \mathrm{mg} / \mathrm{ml})$ for $30 \mathrm{~min}$ of intracellular ROS as detected with CelIROX Green Reagent. CellROX Green imaging analysis of cell damages before (a) and after (b) administration of non-labeled 30 $\mathrm{nm}$ of silica nanoparticles. The rates of cell damages at $30 \mathrm{~min}$ (b) were compared with 0 min (a). CellROX Green (green) and anti-MAP2 (red). We examined 10 neurons with each condition. Scale bars $=50 \mu \mathrm{m}$.

Neuronal cell damage caused by the silica nanoparticle's exposure was measured by means of the $\mathrm{LDH}$, and ROS assay. It has been reported that cell viability, the leakage of LDH and ROS level were determined for their effect on oxidative damage. Quantitative real-time PCR was investigated to analyze the mitochon- 
drial genes expression. These results showed decreased the leakage of LDH and ROS in a dose and time-dependent same manner [21]. About the neural cell damage after the silica stimulation time and the concentration, it carried out in $10 \mathrm{~min}, 30 \mathrm{~min}$ and we wrote $0 \mathrm{~min}$ (without silica) showed as a control at Figure 4 legends. By processing in the silica concentration of $1 \mathrm{mg} / \mathrm{ml}$, and $30 \mathrm{~min}$, since the cell damage was serious, it was then used in Figure 3.

We observed a decrease in the number of dendrites, and only the cell bodies remained at $1 \mathrm{mg} / \mathrm{ml}$ concentration. Furthermore, the silica nanoparticle localized around the neurons but no active uptake into the cell bodies was observed. As LDH leakage and ROS generation were observed by the silica nanoparticle's exposure, we concluded that ROS generation caused cell membrane damage by the silica nanoparticle's exposure, and this might be a primary mechanism of neuronal cell death.

However, to date, little is known concerning the potential adverse effects on the brain associated with exposure to silica. It is a case where it goes into the brain which may cause cerebral conditions, such as Alzheimer's disease. In acting on a neuron, there is a possibility that a neuron disease like Alzheimer's disease will arise, and it may be connected with ROS generating, destruction of a cell, inflammation, etc. It is necessary to perform cytotoxicity assessment of silica nanoparticles in vitro by this experiment method. It leads to the observation by these in vitro seeing the influence on in vivo directly. This result is meaningful as a result which showed that silica nanoparticles acted on brain cell direct. Silica nanoparticles are being used increasingly in diagnosis, imaging, and drug delivery for the central nervous system in recent years. Since the influence of silica may relate to a disease directly, the experiment here becomes important [22].

ROS production might cause mitochondrial dysfunction within the neurons, or induce apoptosis signal such as caspase $3 / 7$, and the cell death is induced. Neural cell damage caused by ROS production has been linked to diseases such as Alzheimer's and Parkinson's disease [6]. In previous studies, $20-40 \mathrm{~nm}$ diameter of silica nanoparticles were used, and ROS generation resulting from silica administration was reported in primary cultures of cortical neurons isolated from postnatal day 3 rat pups [23]. Because primary cultures of cortical neurons from newborn rats contain not only pyramidal cells but also glia cells, the effects of silica nanoparticles are thought to be complicated [23]. Conversely, in this study, we used a prenatal fetal cerebral cortex for assays, in which pyramidal cells are mainly contained. Therefore, our assays are easy to examine the effect of silica nanoparticles on neuronal damage.

It has been reported to the keratinocyte that the $20 \mathrm{~nm}$ silica particle of toxicity is higher than the silica of $>100 \mathrm{~nm}$ and that the particles below $100 \mathrm{~nm}$ go into a brain as previous statement. We experimented by the particles below 100 $\mathrm{nm}$ this time [17].

Yamashita et al. indicated that silica nanoparticles reach the fetal brain fol- 
lowing the administration of $70 \mathrm{~nm}$ silica particles to pregnant mice [2]. However, functional effects of silica nanoparticles on neurons were not assessed in detail. The simple method for the assessment of neuronal damage used in this study will be useful for predicting possible in vivo damage, such as ROS-related damage and LDH leakage from silica nanoparticles.

\section{Conclusions}

We examined the effect of $30 \mathrm{~nm}$ silica nanoparticle's exposure on cortical neurons by means of LDH assay and ROS generation. The cell damage highly depends on the concentration of the silica nanoparticle, and the exposure time. The long-time exposure caused a generation of ROS, and the generated ROS is one of the reasons for the explanation of neurons' damage. This work suggests a possible risk on neurons is the silica nanoparticle localization associated with ROS generation.

\section{References}

[1] Jeong, Y.S., Oh, W.K., Kim, S. and Jang, J. (2011) Cellular Uptake, Cytotoxicity, and ROS Generation with Silica/Conducting Polymer Core/Shell Nanospheres. Biomaterials, 32, 7217-7225. https://doi.org/10.1016/j.biomaterials.2011.06.020

[2] Yamashita, K., Yoshioka, Y., Higashisaka, K., Mimura, K., Morishitam, Y., Nozaki, M., Yoshida, T., Ogura, T., Nabeshi, H., Nagano, K., et al. (2011) Silica and Titanium Dioxide Nanoparticles Cause Pregnancy Complications in Mice. Nature Nanotechnology, 6, 321-328. https://doi.org/10.1038/nnano.2011.41

[3] Jang, J., Oh, J.H. and Stucky, G.D. (2002) Fabrication of Ultrafine Conducting Polymer and Graphite Nanoparticles. Angewandte Chemie International Edition, 41, 4016-4019.

https://doi.org/10.1002/1521-3773(20021104)41:21<4016::AID-ANIE4016>3.0.CO;2 $-\mathrm{G}$

[4] Kato, S., Itoh, K., Yaoi, T., Tozawa, T., Yoshikawa, Y., Yasui, H., Kanamura, N., Hoshino, A., Manabe, N., Yamamoto, K., et al. (2010) Organ Distribution of Quantum Dots after Intraperitoneal Administration, with Special Reference to Area-Specific Distribution in the Brain. Nanotechnology, 21, Article ID: 335103. https://doi.org/10.1088/0957-4484/21/33/335103

[5] Collazos-Castro, J.E., Polo, J.L., Hernandez-Labrado, G.R., Padial-Canete, V. and Garcia-Rama, C. (2010) Bioelectrochemical Control of Neural Cell Development on Conducting Polymers. Biomaterials, 31, 9244-9255. https://doi.org/10.1016/j.biomaterials.2010.08.057

[6] Kwon, O.S., Park, S.J. and Jang, J. (2010) A High-Performance VEGF Aptamer Functionalized Polypyrrole Nanotube Biosensor. Biomaterials, 31, 4740-4747. https://doi.org/10.1016/j.biomaterials.2010.02.040

[7] Abidian, M.R., Corey, J.M., Kipke, D.R. and Martin, D.C. (2010) Conducting-Polymer Nanotubes Improve Electrical Properties, Mechanical Adhesion, Neural Attachment, and Neurite Outgrowth of Neural Electrodes. Small, 6, 421-429. https://doi.org/10.1002/smll.200901868

[8] Ciofani, G., Danti, S., D’Alessandro, D., Ricotti, L., Moscato, S., Bertoni, G., Falqui, A., Berrettini, S., Petrini, M., Mattoli, V., et al. Enhancement of Neurite Outgrowth in Neuronal-Like Cells Following Boron Nitride Nanotube-Mediated Stimulation. 
ACS Nano, 4, 6267-6277. https://doi.org/10.1021/nn101985a

[9] Shih, A.Y., Fernandes, H.B., Choi, F.Y., Kozoriz, M.G., Liu, Y., Li, P., Cowan, C.M. and Klegeris, A. (2006) Policing the Police: Astrocytes Modulate Microglial Activation. Journal of Neuroscience, 26, 3887-3888. https://doi.org/10.1523/JNEUROSCI.0936-06.2006

[10] Perrault, S.D., Walkey, C., Jennings, T., Fischer, H.C. and Chan, W.C. (2009) Mediating Tumor Targeting Efficiency of Nanoparticles through Design. Nano Letters, 9, 1909-1915. https://doi.org/10.1021/nl900031y

[11] Choi, J., Zheng, Q., Katz, H.E. and Guilarte, T.R. (2010) Silica-Based Nanoparticle Uptake and Cellular Response by Primary Microglia. Environmental Health Perspectives, 118, 589-595. https://doi.org/10.1289/ehp.0901534

[12] Kalcheva, N., Albala, J., O’Guin, K., Rubino, H., Garner, C. and Shafit-Zagardo, B. (1995) Genomic Structure of Human Microtubule-Associated Protein 2 (MAP-2) and Characterization of Additional MAP-2 Isoforms. Proceedings of the National Academy of Sciences of the United States of America, 92, 10894-10898.

https://doi.org/10.1073/pnas.92.24.10894

[13] Mao, H., Fang, X., Floyd, K.M., Polcz, J.E., Zhang, P. and Liu, B. (2007) Induction of Microglial Reactive Oxygen Species Production by the Organochlorinated Pesticide Dieldrin. Brain Research, 1186, 267-274.

https://doi.org/10.1016/j.brainres.2007.10.020

[14] Hanada, S., Fujioka, K., Inoue, Y., Kanaya, F., Manome, Y. and Yamamoto, K. (2014) Cell-Based in Vitro Blood-Brain Barrier Model Can Rapidly Evaluate Nanoparticles' Brain Permeability in Association with Particle Size and Surface Modification. International Journal of Molecular Sciences, 15, 1812-1825. https://doi.org/10.3390/ijms15021812

[15] Fujioka, K., Hanada, S., Inoue, Y., Sato, K., Hirakuri, K., Shiraishi, K., Kanaya, F., Ikeda, K., Usui, R., Yamamoto, K., et al. (2014) Effects of Silica and Titanium Oxide Particles on a Human Neural Stem Cell Line: Morphology, Mitochondrial Activity, and Gene Expression of Differentiation Markers. International Journal of Molecular Sciences, 15, 11742-11759. https://doi.org/10.3390/ijms150711742

[16] Nabeshi, H., Yoshikawa, T., Matsuyama, K., Nakazato, Y., Matsuo, K., Arimori, A., Isobe, M., Tochigi, S., Kondoh, S., Hirai, T., et al. (2011) Systemic Distribution, Nuclear Entry and Cytotoxicity of Amorphous Nanosilica Following Topical Application. Biomaterials, 32, 2713-2724.

https://doi.org/10.1016/j.biomaterials.2010.12.042

[17] Park, Y.H., Kim, J.N., Jeong, S.H., Choi, J.E., Lee, S.H., Choi, B.H., Lee, J.P., Sohn, K.H., Park, K.L., Kim, M.K., et al. (2010) Assessment of Dermal Toxicity of Nanosilica Using Cultured Keratinocytes, a Human Skin Equivalent Model and an in Vivo Model. Toxicology, 267, 178-181. https://doi.org/10.1016/j.tox.2009.10.011

[18] Kato, A., Fukazawa, Y., Ozawa, F., Inokuchi, K. and Sugiyama, H. (2003) Activation of ERK Cascade Promotes Accumulation of Vesl-1S/Homer-1a Immunoreactivity at Synapses. Molecular Brain Research, 118, 33-44. https://doi.org/10.1016/j.molbrainres.2003.07.005

[19] Inoue, Y., Kamikubo, Y., Ezure, H., Ito, J., Kato, Y., Moriyama, H. and Otsuka, N. (2015) Presynaptic Protein Synaptotagmin1 Regulates the Neuronal Polarity and Axon Differentiation in Cultured Hippocampal Neurons. BMC Neuroscience, 16, 92. https://doi.org/10.1186/s12868-015-0231-x

[20] Neve, R.L., Harris, P., Kosik, K.S., Kurnit, D.M. and Donlon, T.A. (1986) Identification of cDNA Clones for the Human Microtubule-Associated Protein Tau and 
Chromosomal Localization of the Genes for Tau and Microtubule-Associated Protein 2. Molecular Brain Research, 387, 271-280.

[21] Wu, F.J., Xue, Y., Tang, Q.J., Xu, J., Du, L., Xue, C.H., Takahashi, K. and Wang, Y.M. (2013) Protective Effects of Cerebrosides from Sea Cucumber and Starfish on the Oxidative Damage in PC12 Cells. Journal of Oleo Science, 62, 717-727.

[22] Wang, F., Gao, F., Lan, M., Yuan, H., Huang, Y. and Liu, J. (2009) Oxidative Stress Contributes to Silica Nanoparticle-Induced Cytotoxicity in Human Embryonic Kidney Cells. Toxicology in Vitro, 23, 808-815.

https://doi.org/10.1016/j.tiv.2009.04.009

[23] Haase, A., Rott, S., Mantion, A., Graf, P., Plendl, J., Thunemann, A.F., Meier, W.P., Taubert, A., Luch, A. and Reiser, G. (2012) Effects of Silver Nanoparticles on Primary Mixed Neural Cell Cultures: Uptake, Oxidative Stress and Acute Calcium Responses. Toxicological Sciences, 126, 457-468.

https://doi.org/10.1093/toxsci/kfs003 